ANNALS OF “DUNAREA DE JOS” UNIVERSITY OF GALATI

MATHEMATICS, PHYSICS, THEORETICAL MECHANICS

FASCICLE II, YEAR XII (XLIII) 2020, No. 1

DOI: https://doi.org/10.35219/ann-ugal-math-phys-mec.2020.1.08

\title{
Evolution of Romania's Black Sea coastline. A review
}

\author{
Gabriel Dobrică ${ }^{1, *}$, Carmen Maftei ${ }^{1,2}$ \\ ${ }^{1}$ Ovidius University of Constanta, Doctoral School of Applied Sciences, 58 Ion Vodă Street, RO-900573, \\ Constanta, Romania \\ ${ }^{2}$ Transilvania University of Brasov, Faculty of Civil Engineering, 5 Turnului Street, RO-500152, Brasov, \\ Romania \\ *Corresponding author: gabriel.dobrica@yahoo.com
}

\begin{abstract}
In the context of growth blue strategy, an important place is provided to ensure sustainable development of sea activities which could not be realized without a good knowledge of the coastline. The shoreline of the Romanian Black Sea is about $240 \mathrm{~km}$ long from Musura Golf (in North) to Vama Veche (in South). This area has an important place in the country's economy due to its natural and cultural heritage and tourism potential but coastline land use is subject to great threat: coastal erosion. This study aims to investigate the Romanian Black Sea coast in terms of its evolution over time in order to establish the main vulnerabilities and the principal indexes that characterize it.
\end{abstract}

Keywords: Climate change, shoreline, sea level rise, Black Sea.

\section{INTRODUCTION}

In the context of growth blue strategy, an important place is provided to ensure sustainable development of sea activities which could not be realized without a good knowledge of the coast area. Knowing the position of the coastline/shoreline over time is a crucial element for all stakeholders interested in the development of the coastal area. To analyse the time and space variability of the coastline a functional definition is necessary [1]. Shore area is defined for the first time by D.W. Johnson in 1919 [2] in terms of morphological and genetic criterion as a unit extension of coast area. Based on D.W. Johnson transversal profile today is widely accepted a schematic representation of a shoreface profile as that presented in figure 1, where the coastline is the limit between shore and coast and shoreline varied between high and low water level. Johnson [2] provide also the most "simplistic" definitions for shoreline "the line where land and water meet". Despite its simplicity, this "line" is very difficult to highlight due to its variability in time and space. The shoreline position changes over time because of the dynamic of water levels through the season or tide and storm season, accelerated sea level rise, sediment movement, etc.

\section{EXPERIMENTAL}

The variation of the shoreline can be examined from multiple available data sources: historical map and photography, military map, photograms, ortophotomap, satellite images. Usually, data from different sources are used to achieve the desired temporal coverage [1].

Historical photographs provide only general information about the specific morphological feature (eg. the presence of a beach or coastal cliff) and present major issues regarding scale or control points as well as a lack of information about sea conditions at the time the photo was taken) [3]. This makes the accurate mapping of the historical shoreline very difficult (Fig.1), and thus, they represent limited importance. 


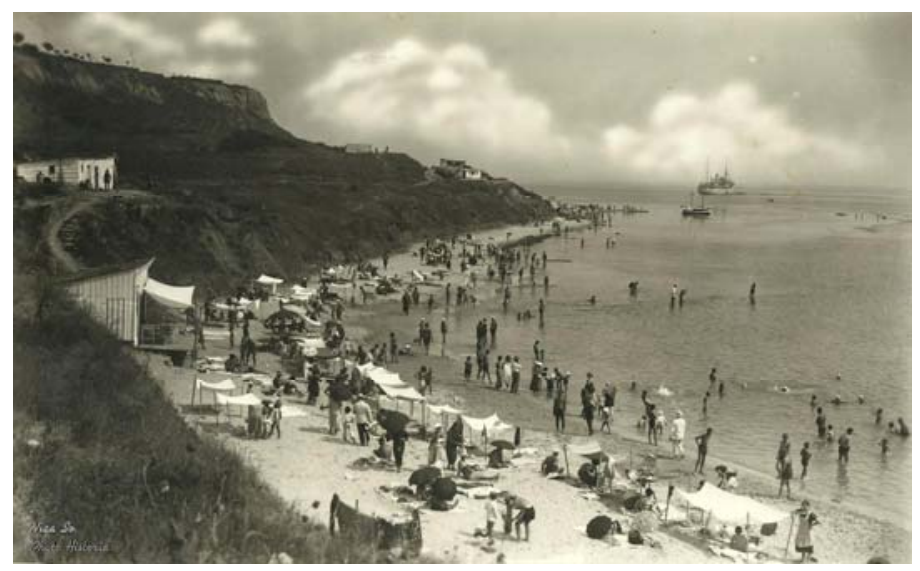

Fig. 1. Photo from 1930, Eforie Sud (source [7])

Historical maps and charts focus on decorating and as such, they tend to treat the technical part as non-important. As a result, they almost never specify the methods used for mapping and they do not contain any accuracy assessment, sometimes not even mentioning the selected shoreline feature. The maps used are military maps, Shooting master plans, scale 1: 20000 (Fig. 2), in the Lambert-Cholesky projection system (1917-1959).

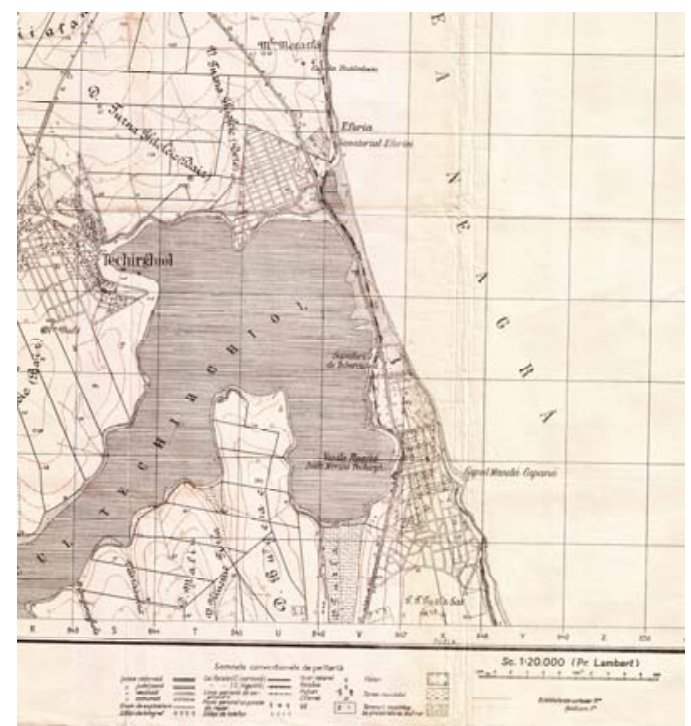

Fig. 2. Shooting master plans; Techirghiol area (source MAPSTER - Zestawienia map) [9]

The best historical data source for analyzing previous shoreline fluctuations are aerial photographs. In the 1920 `s, the coast began to be monitored and vertical aerial photographs were taken and collected, but as aerial photography was a new field, the pace of technological advance allowed for reasonable photographs to be taken only late in the 1930's. The time frame in which the photographic survey is being carried out varies greatly and is specific to every site according to its importance at the respective moment (as well as a tendency to be carried out after significant storms) although the aerial photographs provide proper spatial coverage. When using photographs for the study, it implies that the identified coastline is always based on a visible feature.

The aerial photographs for determining the shoreline were taken in 1952 and made available by the Bucharest Geospatial Defense Intelligence Agency (Fig.4). 


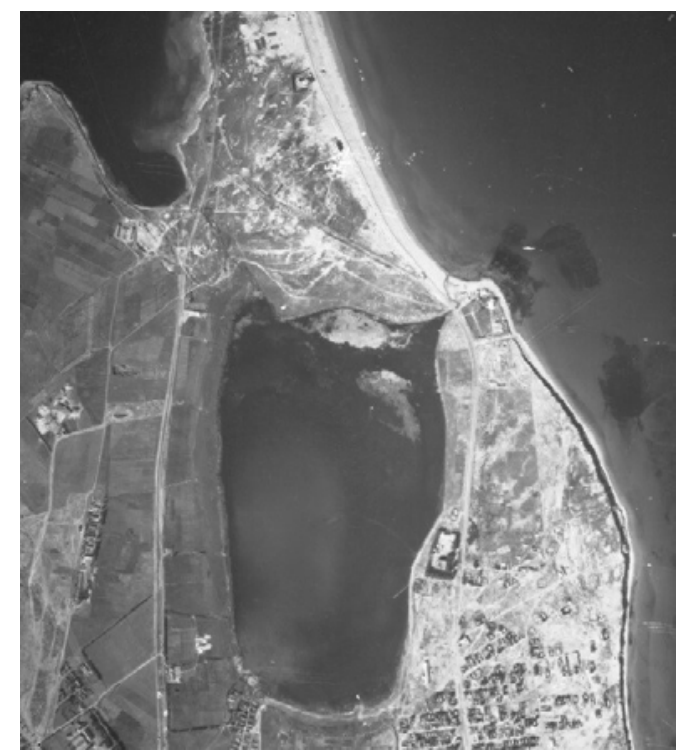

Fig. 3. Aerial photos, Lake Tabacarie Constanta [8]

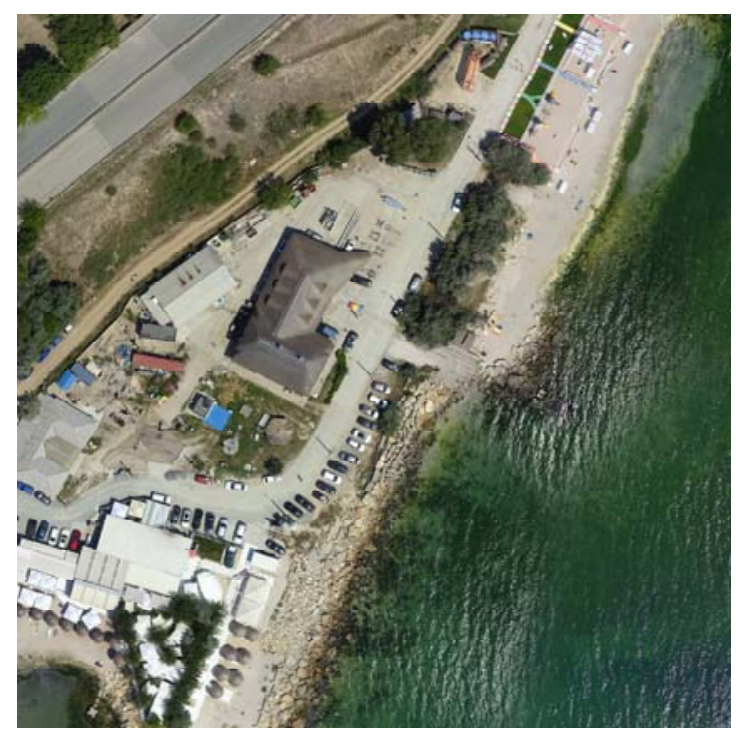

Fig. 4. Orthophotoplan 2020, Agigea fishery (photo author)

The orthophotoplan is an aerial image that has corrected the errors due to the inclination of the plane at the time of taking, the errors due to the uneven scale of the frame, and the level differences of the relief. The orthophotoplan is based on a series of processes such as aero triangulation, digital terrain model (DTM), orthorectification, and mosaicking.

\section{RESULTS AND DISCUSSION}

In order to evaluate the Black Sea shoreline changes, we could use the "Digital Shoreline Analysis System" (DSAS) software [6]. This program is an extension of the ArcGIS desktop software and it could provide an analysis of the shoreline evolution based on a statistical approach. It includes a model for generating future shoreline positions, calculated from a baseline. For the Romanian coast, we will use the baseline established by Law 17/1990, regarding the legal regime of the inland maritime waters, of the territorial sea, of the contiguous zone, and of the exclusive economic zone of Romania. 

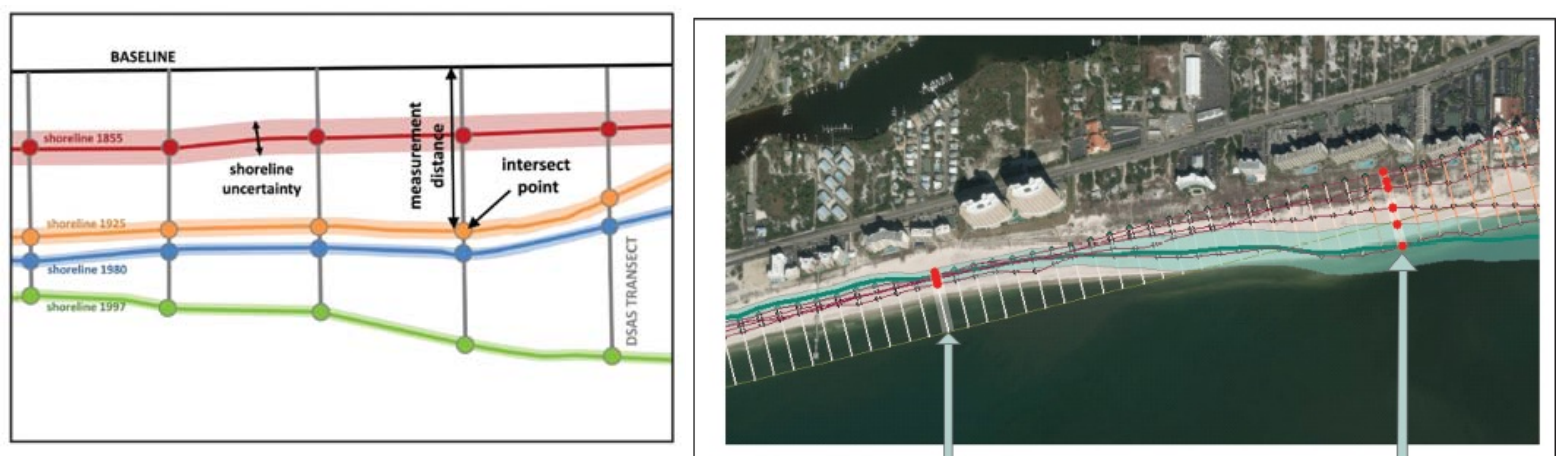

Fig. 5. The measurement distance from the baseline to each intersect point (source www.usgs.gov) [6]

\section{CONCLUSIONS}

Knowing the evolution of the shoreline we can know the areas with high erosion located on the Romanian coast and forecast the areas with erosion that will occur. With these data, we know how to protect our natural and cultural heritage, the tourist potential, and the country's economy. The seas and oceans are the engines of the European economy and have great potential for innovation and growth. It is the maritime contribution to achieving the goals of the Europe 2020 strategy for smart, sustainable, and inclusive growth.

\section{Acknowledgements}

„This work is supported by the project ANTREPRENORDOC, in the framework of Human Resources Development Operational Programme 2014-2020, financed from the European Social Fund under the contract number 36355/23.05.2019 HRD OP /380/6/13 - SMIS Code: 123847."

\section{References}

1. Boak, E. H., \& Turner, I. L.. Shoreline Definition and Detection: A Review. Journal of Coastal Research, 21(4 (214)) (2005) 688-703. https://doi.org/10.2112/03-0071.1.

2. Johnson, D. W. (1919). Shore processes and shoreline development. New York, John Wiley \& Sons, Inc.; etc.]. http://archive.org/details/shoreprocessesa00johngoog.

3. Dolan, R.; Hayden, B.P., and May, S., Erosion of the US shorelines. In: Komar, P.D. (ed.), CRC Handbook of Coastal Processes and Erosion. Boca Raton, Florida: CRC Press, pp. 285299, 1983.

4. Morton, R.A., Accurate shoreline mapping: past, present, and Shoreline Definition and Detection 703 Journal of Coastal Research, Vol. 21, No. 4, 2005 future. Proceedings of the Coastal Sediments '91 (Seattle, Washington), pp. 997-1010., 1991.

5. Morton, R., Miller, T., \& Moore, L. (2004). National Assessment Of Shoreline Change: Part 1 Historical Shoreline Changes And Associated Coastal Land Loss Along The U.S. Gulf Of Mexico.

6. Himmelstoss, E.A., Henderson, R.E., Kratzmann, M.G., and Farris, A.S., 2018, Digital Shoreline Analysis System (DSAS) version 5.0 user guide: U.S. Geological Survey OpenFile Report 2018-1179, 110 p., https://doi.org/10.3133/ofr20181179 available at: https://www.usgs.gov/centers/whcmsc/science/digital-shoreline-analysis-system-dsas?qtscience center_objects $=0 \#$ qt-science center objects

7. www.economica.net. accesed at: 15.06 .2020

8. www.geomil.ro. accesed at: 15.06.2020.

9. http://igrek.amzp.pl/. accesed at: 15.06 .2020 